Dr NIKOLA ŽUTIĆ, naučni savetnik

Institut za savremenu istoriju

UDK 94:327(497.1:456.31)"1945/1966"(093.2)

Beograd, Trg Nikole Pašića 11

272(497.1:456.31)"1966"(093.2)

\title{
PROTOKOL JUGOSLAVIJE I VATIKANA IZ 1966. GODINE*
}

\begin{abstract}
APSTRAKT: $U$ članku se analizira proces normalizacije odnosa između Vatikana i jugoslavenske države (od 1945. do 1966). Taj proces se kretao od otvorenog neprijateljstva između crkve i države do postepenog pronalaženja modusa poboljšanja odnosa, koji su se razvijali u skladu sa međunarodnom konstelacijom snaga.
\end{abstract}

Ključne riječi: Protokol, SFRJ, Vatikan, Sveta Stolica, Rimokatolička crkva, II vatikanski koncil, Komisija za vjerska pitanja, SSSR, SAD, Pavle VI, Vejvoda

Diplomatski odnosi između Kraljevine SHS i Vatikana, uspostavljeni poslije vatikanskog priznanja nove države 1920. godine, nisu prekidani ni tokom Drugog svjetskog rata. Time je održan kontinuitet međunarodnog priznanja Jugoslavije, koji je potvrđen i u „novoj“ Jugoslaviji imenovanjem papskog nuncija oktobra 1945. godine. Međutim, na inicijativu komunističke Jugoslavije ipak je došlo do prekida diplomatskih odnosa decembra 1952, zbog otvorenog miješanja Svete Stolice u unutrašnja pitanja Jugoslavije, ispoljavanja neprijateljske djelatnosti i, naročito, zbog toga što je Vatikan imenovao za kardinala Alojzija Stepinca, optuženog za saradnju sa poglavnikom Antom Pavelićem i Nezavisnom Državom Hrvatskom i potom osuđenog od novih komunističkih vlasti.

U jugoslavenskoj državnoj Komisiji za vjerska pitanja isticali su da prekid odnosa sa Sv. Stolicom nije značio i onemogućavanje Rimokatoličke crkve (RKC) da i dalje djeluje u okviru Ustava i jugoslavenskih zakona. Vlada je, štaviše, uputila poziv rimokatoličkom Episkopatu u Jugoslaviji da se u cilju sređivanja odnosa crkva - država, razmotri pitanja koja su interesirala

* Rad je deo projekta Srpsko društvo u jugoslovenskoj državi u 20. veku: između demokratije i diktature (177016), koji finansira Ministarstvo prosvete, nauke i tehnološkog razvoja Republike Srbije. 
Rimokatoličku crkvu. Iako su usljedili izvjesni kontakti u tom smislu, Episkopat se po nalogu Sv. Stolice proglasio nenadležnim za regulisanje odnosa sa državom, izjavljujući da su oni bili u isključivoj nadležnosti Sv. Stolice. Jednostavno rečeno, Vatikan i Rimokatolička crkva iz ideoloških i političkih razloga nisu željeli sređivanje odnosa sa „komunističkom“ Jugoslavijom, bez obzira na činjenicu da su to isto učinile druge crkve i vjerske zajednice. Domaći zagovornici zbližavanja Vatikana i Jugoslavije, međutim, isticali su da je „naša dosljednost u stavu prema Crkvi, stvorila kod dobrog dijela katoličkog klera ubjeđenje da je moguće i neophodno ići na sređivanje odnosa s državom u okviru Ustava i Zakona o pravnom položaju vjerskih zajednica iz 1953. godine“. Tome je, prema njihovom mišljenju, doprinjela i „afirmacija naše zemlje na međunarodnom planu“. ${ }^{1}$

Udaljavanjem Jugoslavije od komunističkog Istočnog bloka pedesetih godina se pojavljuju zapadni zagovornici zbliženja Jugoslavije i Vatikana, prvenstveno radi pridobijanja zapadnog rimokatoličkog dijela države. Istoričar Dragoljub Živojinović piše da su američki i britanski posmatrači bili naklonjeni Vatikanu i Rimskoj crkvi. Sam proces nadbiskupu Stepincu 1946. zapadne zemlje su posmatrale kao nasilje nad pravdom, što je naravno bilo mišljenje i Vatikana. ${ }^{2}$

Otvoreno neprijateljstvo prema režimu u Jugoslaviji Vatikan je iskazao tokom sukoba Jugoslavije i Informbiroa 1948-55. godine. U Vatikanu su procjenjivali da je raskid sa SSSR-om bio vještački, privremen i neiskren. Po ocjeni Živojinovića, sukob Jugoslavije sa Informbiroom imao je dalekosežne i nepredvidive posljedice: „Doveo je do prestanka jednodušnosti u stavovima Vatikana i SAD prema Jugoslaviji. Njihova dotadašnja saradnja i pogledi, određeni ideološkim i političkim razlozima, ustupili su mjesto strategijskim i odbrambenim potrebama SAD i zapadne Evrope. To je dovelo do međusobnog razlaza. Dok su SAD i zapadnoevropske zemlje slijedile puteve mirenja i saradnje, Vatikan je nastavio politiku sukobljavanja. To je pokazivalo dubinu i nepremostivost njegovog spora sa Jugoslavijom". ${ }^{3}$

Politika mirenja i saradnje, zaključuje Živojinović, ubrzo je donijela određene rezultate: „Pod pritiskom SAD, zapadnih zemalja i javnog mnjenja u svetu, kao i potrebe da obezbedi njihovu podršku i pomoć u sukobu sa SSSR-om, jugoslovenski režim je postepeno ublažavao svoje držanje prema Crkvi." Pritisak SAD na Jugoslaviju, koji je Josip Broz blagonaklono prihvatio, doveo je do uslovnog oslobođenja nadbiskupa Stepinca i njegovog pre-

${ }^{1}$ AJ, fond 144, Komisija za verska pitanja FNRJ (SFRJ), f. 101, Informacija Savezne komisije za verska pitanja o odnosima između SFRJ i Sv. Stolice, 26. maj 1966.

2 D. Živojinović, Vatikan, Katolička crkva i jugoslovenska vlast 1941-1958, Beograd 1994, 435.

${ }^{3}$ Isto, 436. 
bacivanja iz zatvora u Lepoglavi u kućni pritvor u Krašiću. U skladu sa Brozovim zaoštravanjem sa Informbiroom i SSSR-om uslijedilo je sve čvršće jugoslavensko političko vezivanje za Sjedinjene Američke Države, od kojih je stizala sve jača podrška vezana za odnose sa Vatikanom i Rimokatoličkom crkvom.

Vatikan se, naročito od 1959, počeo suzdržavati od otvorenijih napada na Jugoslaviju i sve je više iz pragmatičnih političkih razloga uviđao potrebu regulisanja crkveno-državnog odnosa. U Saveznoj komisiji su isticali da su ove tendencije našle odraz u novoj politici Rimokatoličke crkve koju je zacrtao i vodio papa Jovan XXIII. Episkopat RKC u Jugoslaviji uputio je 1960. godine predstavku Saveznom izvršnom vjeću u kojoj su biskupi izrazili spremnost da svojim učešćem doprinesu poboljšanju odnosa RKC i države. Ovakav stav Episkopata izražavao je promjenu politike Sv. Stolice, koja je sve više davala na znanje kako je spremna da uputi apostolskog delegata u Jugoslaviju. Dakle, procesi prilagođavanja RKC „savremenim uslovima" i II vatikanski koncil, ${ }^{4}$ održan od 1962. do 1965, uslovili su da Sv. Stolica i Rimokatolička crkva u zemlji preispitaju svoje odnose i prema Jugoslaviji, a naročito prema „istočnoj pravoslavnoj braći“ u Jugoslaviji.

Vatikansko „prilagođavanje savremenim uslovima“ zapazila je i istoričarka Katarina Spehnjak, koja je navela „kako je iz povijesti Katoličke crkve poznato da se tako veliki skupovi, poput koncila, održavaju samo u kriznim vatikanskim vremenima". Tako se Vatikan nastojao prilagoditi savremenom trendu, pošto „sprečavanje razvoja socijalizma nije ostvareno“. ${ }^{5}$ Pored mogućnosti ekumenskog zbliženja sa pravoslavnima, koje je otvarao II vatikanski koncil, planirani Protokol sa Jugoslavijom Vatikanu je mogao

${ }^{4}$ U uvodnom govoru na II vatikanskom koncilu, koji je počeo 1. oktobra 1962, papa Jovan (Ivan) XXIII (1958-1963) istakao je da „i vjerskim učenjem i doktrinama crkva mora ići u susret potrebama savremenog života, ali i sopstvenom obnovom dokazivati vrijednost Hristove vjere“. Rad koncila je počeo po komisijama koje su razmatrale pripremljene nacrte. U komisiji „O sredstvima komunikacije“ trebalo je da se vodi rasprava o nacrtu „Ujedinjenja crkava“. O tome je naročito na koncilu raspravljao novi papa Pavle VI (1963-1978), koji je „odijeljenoj braći s istoka“ uputio slijedeću značajnu poruku: „Ako su sa naše strane učinjene greške za nastalo odvajanje..., mi molimo i najponiznije tražimo od Boga da nam oprosti, a to isto molimo i braću, ako se osjećaju povrijeđenima. I mi smo spremni oprostiti kada smo predmet optužbi bili mi, tokom dugog vremena naših sporova i razdvojenosti“. Kako navodi Petar Leposavić, za oko dvije stotine konzervativnih episkopa-delegata „bilo je neshvatljivo da sabor usvaja tako 'jeretičke' i 'modernističke stavove, pogubne po crkvu, jer toga nije bilo od Konstantina Velikog“. Konačno je 18. novembra 1965. usvojena i Deklaracija o slobodi vjeroispovjesti, što je predstavljalo veliku prekretnicu u vjerskoj politici Rimske crkve „u posljednjih XVI vjekova“: „Prvi put rimokatolička crkva je javno priznala ravnopravnost svim drugim vjerama i crkvama koje su do tada za nju bile 'jeretičke', 'šizmatičke', ili čak ateističke" - P. Leposavić, Papstvo, Beograd 2005, 356-357.

${ }^{5}$ K. Spehnjak, Tumačenje Protokola o odnosima Jugoslavije i Vatikana iz 1966. u političkoj javnosti Hrvatske, u: Dijalog povjesničara - istoričara, 3, Zagreb 2001, 476. 
omogućiti uspostavljanje boljih odnosa i sa nesvrstanim zemljama, kod kojih je Jugoslavija uživala veliki ugled. Jugoslavija je, s druge strane, imala interes da u rimokatoličkim zemljama dobije podršku kako bi se smanjilo antijugoslavensko djelovanje dijela rimokatoličkog svećenstva i ustaške političke emigracije, i ublažila antikomunistička propaganda protiv socijalističkih zemalja. ${ }^{6}$

Određenije ispitivanje oportunosti vezane za regulisanje odnosa između Socijalističke Federativne Republike Jugoslavije (SFRJ) i Sv. Stolice otpočelo je 1962 (u godini II vatikanskog koncila), a već 1963. došlo je do neposrednih susreta između predstavnika Sv. Stolice i Ambasade SFRJ u Rimu. Razgovori su imali više informativni karakter, jer su pokrenuta samo osnovna pitanja koja je trebalo rješavati kako bi se normalizovali odnosi. Vatikan je imao interes da ojača položaj Crkve u zemlji i obezbijedi povoljnije uslove za svoje veze sa "neangažovanim“ (nesvrstanim) zemljama, zatim da ojača pozicije RKC u rješavanju problema sa kojima se ona susretala u svijetu. Interesima Vatikana pridružili su se i italijanski nacionalni interesi. ${ }^{7}$

Jugoslavenske vlasti su očekivale da će sređivanjem odnosa sa Vatikanom SFRJ pružiti podršku umjerenijim i pozitivnijim snagama i tendencijama u politici Vatikana i pozitivnim kretanjima u Rimokatoličkoj crkvi u svijetu. Kako se smatralo, to je trebalo doprinjeti boljem razumijevanju politike Jugoslavije u rimokatoličkom svijetu, slabljenju antijugoslavenske aktivnosti svećeničke i druge emigracije, kao i otupljivanju antikomunističke propagande, koja je koristila nesređeno stanje odnosa Rimske crkve i socijalističkih država.

Sredinom šezdesetih godina još uvijek nije bilo jasno kako će se Vatikan i RKC prilagoditi „savremenom razvitku“ i kakvu će politiku formirati u međunarodnim odnosima. U jugoslavenskim krugovima je zaključeno da je preuranjeno davati ocjene politike pape Pavla VI: „Iako se on više puta javno izjasnio za nastavljanje politike Ivana XXIII, ipak su se mogle postaviti određene rezerve $u$ pogledu njegovih daljnjih namjera. Tako ima osnova za pretpostavku da se odnosi sa socijalističkim zemljama neće razvijati onako kako je to bilo započeto za vrijeme Ivana XXIII; on (Pavle) podržava ideju o ujedinjenoj Evropi, akciju za ujedinjenje hrišćanstva želi da koristi ne samo na vjerskom već i na političkom planu. Pored ovoga, treba imati u vidu i činjenicu da je još u toku Drugi vatikanski koncil, koji treba tek da zauzme stavove o osnovnim pitanjima politike Rimokatoličke crkve (crkva i savremeni svijet, reforme u organizaciji i metodu upravljanja, uje-

\footnotetext{
${ }^{6}$ Isto, 477.

${ }^{7}$ AJ, fond 144, Komisija za verska pitanja FNRJ (SFRJ), f. 101, Zabeleška o odnosima SFRJ - Vatikan, 17. februar 1964.
} 
dinjenje hrišćanstva - ekumenizam i dr.)“. U dotadašnjem radu koncila ispoljavale su se duboke podvojenosti između konzervativnijeg i liberalnijeg dijela kardinala i biskupa, kao izraz značajnih razlika u Rimokatoličkoj crkvi. $^{8}$

Jugoslavenske vlasti su sa zadovoljstvom konstatovale da je odnos RKC u Jugoslaviji prema državi pokazivao tendenciju stalnog poboljšavanja: „To je rezultat dosljedne politike države prema crkvi, koja je, pored ostalog, stvorila mogućnosti da se putem neposrednih kontakata sa biskupima i drugim predstavnicima crkve, rješavaju u okviru zakona, konkretna pitanja“. Ipak se isticalo da se iz ideološko-političkih razloga dio višeg i manji dio nižeg klera aktivno suprotstavljao poboljšavanju odnosa, nailazeći u tome na podršku određenih snaga u Vatikanu i drugim rimokatoličkim krugovima $u$ inostranstvu. Jedan dio svećenstva nastojao je da podstiče rimokatolički klerikalizam, da jača vjerski i ideološki uticaj na djecu i omladinu i da svoja nastojanja usmjerava u pravcu proširivanja uticaja i na javni život. Konstatovano je da ovakve pojave nisu bile praćene grubim političkim ispadima, ali su izazivale povremene poteškoće u odnosima sa pojedinim biskupima i drugim predstavnicima crkve.

Povodom tih prvih kontakta tokom 1963. godine, predstavnik Vatikana predložio je jugoslavenskoj strani slijedeća rješenja:

a) Vatikan prihvata regulisanje odnosa sa SFRJ na osnovu Ustava i Zakona o pravnom položaju vjerskih zajednica i ne insistira na pismenom već bi se zadovoljio i usmenim sporazumom.

b) Vatikan ne uslovljava sređivanje odnosa između države i RKC u zemlji prethodnim obnavljanjem diplomatskih odnosa između SFRJ i Vatikana. Sređivanje odnosa sa crkvom u zemlji i uspostavu odnosa sa Vatikanom treba razmatrati istovremeno. Vatikan bi se zadovoljio sada uspostavljanjem odnosa na konzularnom nivou ili povremenim slanjem svog delegata u zemlju.

c) Ako jugoslavenska strana ne želi sređivanje odnosa putem pregovora Vatikan - SFRJ, Vatikan je spreman „da uz jugoslavenski episkopat i pored njega radi na tome da se odnosi Episkopat - Država srede“.

d) Vatikan smatra da su sazreli uslovi da se dosadašnji informativni razgovori o sređivanju odnosa podignu na nivo pregovora Vejvoda - Samore.

U vezi sa položajem i djelovanjem Rimske crkve u zemlji, predstavnik Vatikana postavio je slijedeće zahtjeve:

a) Vatikan traži da se obezbijedi dosljedna primjena ustavnih i zakonskih odredaba u pogledu slobode vjeroispovijesti, a posebno da vjernici RKC (profesori, učitelji i drugi) ne budu diskriminisani prilikom prijema $u$ prosvjetnu službu, ili da usljed toga što posjećuju crkve gube službu u ovoj

\footnotetext{
${ }^{8}$ Isto.
} 
struci i da se za posjećivanje vjeronauke ne traži pismeni pristanak oba, već jednog roditelja.

b) Vatikan će se povinovati zakonima države, ali se RKC ne može iz principijelnih razloga odreći svog stava o pitanjima kao što su: da se katolička štampa ne ograničava i da joj se ne prave teškoće; da se udruženja rimokatoličkih svećenika prepuste biskupima; da se škole za spremanje svećenika izjednače u pravima sa ostalim školama u zemlji, a njihovim polaznicima pruže sve povlastice koje imaju polaznici ostalih škola; da se u cilju obavljanja određenih vjerskih obreda svećenicima omogući, u okviru kućnog reda, pristup bolnicama, kazneno-popravnim domovima, internatima i tome slično.

Jugoslavenska strana je procijenila da su navedeni stavovi i zahtjevi mnogo realniji od onih koje je Vatikana isticao $u$ ranijim razgovorima. U razgovoru sa predstavnicima Vatikana, predstavnici Saveznog izvršnog veća su istakli slijedeća pitanja:

a) RKC treba da sređuje odnose sa državom na osnovu Ustava i Zakona o pravnom položaju vjerskih zajednica. Pored razgovora koji će se o tome voditi sa Vatikanom, konkretna pitanja iz ovih odnosa biskupi treba da rješavaju sa vlastima u zemlji.

b) Rimokatolička crkva treba da odustane od svake političke i propagandne aktivnosti uperene protiv političkog i društvenog uređenja SFRJ.

c) Vatikan i RKC treba da sprečavaju antijugoslavensku djelatnost rimokatoličke svećeničke emigracije. Svoj uticaj treba da založe i za onemogućavanje neprijateljske djelatnosti emigracije (terorizam, napadi na integritet Jugoslavije i drugo).

d) Prilikom imenovanja biskupa i kardinala vlada SFRJ treba da ima mogućnost prigovora, kako je to uobičajeno u drugim zemljama.

Premda je predstavnik Vatikana iznio spremnost da preuzme izvjesne pozitivne obaveze $u$ odnosu na većinu iznjetih pitanja, on je o svim pitanjima izrazio rezerve. U zahtjevima koje je iznio u pogledu daljnjeg položaja RKC u zemlji, premda je zauzeo umjereniji i tolerantniji stav nego ranije, predstavnik Vatikana nije bio sasvim određen, a nije se stiglo do uvjerenja da su navedeni zahtjevi Vatikana predstavljali njihove konačne zahtjevi u odnosu na državu. Jugoslavenska strana, dakle, još uvijek nije mogla izreći potpunu ocjenu vatikanskih stavova. Na osnovu predočenih vatikanskih zahtjeva jugoslavenska strana je predložila slijedeće:

1. „Da bi se moglo jasnije i sa više sigurnosti sagledati na kojim osnovama Vatikan postavlja odnose sa SFRJ, koliko je spreman da prihvati naše predloge i koji su njegovi maksimalni zahtjevi, kao i dokle mi možemo $\mathrm{u}$ ovim odnosima realizovati naše unutrašnje i međunarodne interese, razgovore s predstavnikom Vatikana treba za sada nastaviti na dosadašnjem 
nivou, tj. preko savetnika ambasade $u$ Rimu. U tim, za sada informativnim razgovorima, treba još jasnije precizirati stavove Vatikana po pitanjima koje on postavlja, kao i po pitanjima koja su s naše strane postavljena, kako bi se mogli utvrditi realni okviri i mogućnosti od kojih treba poći u daljem sređivanju odnosa sa Vatikanom, kao i u rešavanju konkretnih pitanja koja spadaju u nadležnost Episkopata u zemlji. Ako Vatikan zatraži podizanje sadašnjih informativnih razgovora na nivo pregovora Vejvoda - Samore, takvu inicijativu ne bi trebalo odbijati. Ali za vođenje pregovora na ovom nivou treba obezbediti povoljne rezultate $u$ prethodnim informativnim razgovorima.

2. U razgovorima predstavnik ambasade treba da iznese da nadležni jugoslovenski faktori povoljno ocenjuju razvoj odnosa između SFRJ i Vatikana, a i Države i RKC u zemlji; da su ostvareni povoljni uslovi i atmosfera za njihov širi i brži razvoj; da SFRJ visoko ceni ispoljena nastojanja pape Pavla VI i Vatikana u tom pravcu i spremna je da se založi za postizanje bolje i trajnije osnove za dalje unapređivanje međusobnih odnosa, u skladu s njenim demokratskim unutrašnjim razvitkom, interesima mira i međunarodne saradnje.

3. Osnovu za dalje sređivanje odnosa RKC i SFRJ čini Ustav SFRJ, Zakon o pravnom položaju verskih zajednica i drugi propisi u zemlji. Potvrđeno je da se odnosi s Vatikanom mogu utvrditi usmenim dogovorom koji bi obavezivao sve zainteresovane strane. ${ }^{9}$ Prihvatajući kompetencije Vatikana, smatramo da bi kao rezultat dogovora s Vatikanom isti trebao da ovlasti Episkopat u zemlji da rešava s predstavnicima Države pitanja koja su od neposrednog interesa za crkvu u zemlji. Kada se radi o pitanjima koja su u nadležnosti republika, opština i srezova, ista treba da rešavaju predstavnici crkve i ovih društveno-političkih zajednica.

4. Mogu se prihvatiti sugestije Vatikana da u sadašnjoj fazi odnosa, a po uspešno završenim razgovorima s Vatikanom, a zatim i sa Episkopatom u zemlji, Vatikan povremeno šalje papskog delegata u Jugoslaviju. Iako ovaj delegat ne bi predstavljao RKC kod Države, on bi imao pune mogućnosti da se kod nadležnih državnih organa informiše o odnosima države prema RKC i stavovima po pojedinim pitanjima. U slučajevima kad se u ovoj fazi odnosa bude ukazivala potreba za kontakte s Vatikanom, to se može činiti preko ambasade u Rimu.

5. U slučaju uspešno završenih razgovora svaka strana bi prišla realizaciji utvrđenih dogovora na način kako se utvrdi u razgovorima." 10

Predstavnici vlade SFRJ i Sv. Stolice nastavili su razgovore u Rimu od 26. juna do 7. jula 1964. godine. Mada su svi dotadašnji razgovori imali

\footnotetext{
${ }^{9}$ Isto.

${ }^{10}$ Isto.
} 
više informativan karakter, ipak su pokrenuta osnovna pitanja koja je trebalo hitno rješavati zbog poremećenih odnosa. Prethodni, u dobroj mjeri neformalni razgovori omogućili su zvaničnim pregovaračima da realnije razmatraju pitanja od interesa za obe strane i postignu saglasnost u onim pitanjima za koja su se u tadašnjim uslovima mogla naći zajednička rješenja.

Tadašnji analitičari su procjenili da bi SFRJ sređivanjem odnosa sa Vatikanom pružila podršku umjerenijim snagama i tendencijama u politici Sv. Stolice i realnijim kretanjima u Rimokatoličkoj crkvi u svijetu. S druge strane, stekla bi se izvjesna prednost i time što bi se ojačao položaj „pozitivnih rimokatoličkih snaga" $u$ zemlji. Procjenjivalo se da bi sređeni odnosi doprinjeli boljem razumijevanju politike Jugoslavije u rimokatoličkom svijetu, slabljenju antijugoslavenske aktivnosti svećenika i druge emigracije i otupljivanju antikomunističke propagande koja je koristila nesređeno stanje odnosa između RKC i socijalističkih država. Smatralo se i da bi se sređivanjem odnosa sa Sv. Stolicom dala podrška "lijevim snagama“ i ostalim „progresivnim pokretima“ na Zapadu u borbi protiv „raznih klerikalnih i konzervativnih partija i udruženja“". ${ }^{11}$

Interesi Vatikana da sredi odnose sa Jugoslavijom ogledali su se u činjenici što je nastojao da ojača položaj crkve u Jugoslaviji i obezbjedi joj bolje uslove za djelovanje. Vatikan je želio da obezbjedi povoljne uslove za svoje veze sa nesvrstanim zemljama i da ojača pozicije Rimske crkve prilikom rješavanja problema sa kojima se ona susretala u savremenom svijetu. Poslije prvih „preliminarnih“ razgovora Sv. Stolica je procijenila da su stanje i položaj RKC u Jugoslaviji povoljniji nego u drugim zemljama realnog socijalizma, pa su otpočeli i zvanični pregovori o sređivanju odnosa sa RKC.

Poslije prvih, više informativnih i preliminarnih razgovora (tokom 1963. i 1964), zvanični pregovori između Vatikana i SFRJ vođeni su u Beogradu od 15. do 23. januara 1965, nastavljeni od 29. maja do 8. juna 1965. i završeni u Rimu 1966. godine (vođeni od 18. aprila do 25. aprila 1966).

Tokom januarskih razgovora 1965. godine ponovo su razmotrene liste pitanja koja su ranije postavile obe strane. Poslije toga delegacija Sv. Stolice otputovala je iz Beograda u Rim na konsultovanje. Obe strane su prišle ovim pregovorima s ciljem da srede međusobne odnose, bez iluzija da će riješiti sva sporna pitanja. Predstavnici Vatikana su izjavili da „neće činiti nepremostive teškoće" da se položaj Rimokatoličke crkve u SFRJ reguliše unilateralno, tj. na bazi Ustava i zakona, kad se to već do tada nije moglo učiniti na bilateralnoj osnovi putem konkordata ili sličnog međunarodnog sporazuma. Izrazili su, međutim, želju da se prilikom donošenja zakona o

${ }^{11}$ Isto, Informacija Savezne komisije za verska pitanja o odnosima između SFRJ i Sv. Stolice, 26. maj 1966. 
pravnom položaju RKC vodi računa o „željama i težnjama“ Vatikana, koji po mogućnosti terba da bude upoznat $s$ donošenjem zakona o regulisanju pravnogi položaja vjerskih zajednica. Pri tome, treba mu omogućiti da iznese svoje mišljenje. Odvojenosti crkve od države ne mora biti razlog loših odnosa, ako iz toga ne bi rezultirao neprijateljski stav države prema crkvi i religiji - istakli su predstavnici Sv. Stolice.

Svoje stavove predstavnici Vatikana su u dobroj mjeri formulisali na informacijama jugoslavenskih biskupa, koje su tokom pregovora izazivale negativne efekte: „To se zapazilo i po sadržaju njihove liste pitanja, jer u stvari predstavlja siže dosadašnjih predstavki koje su jugoslavenski biskupi upućivali vladi ili drugim organima vlasti. Osjećalo se da predstavnici Sv. Stolice nešto drukčije ocjenjuju stvarni položaj i mogućnosti djelovanja crkve u Jugoslaviji i da šire gledaju na sređivanje odnosa sa SFRJ, od stavova koje imaju neki jugoslavenski biskupi. Ali o nizu značajnih pitanja (pitanje emigracije, imenovanje biskupa, vaspitanje omladine, svećenička udruženja i sl.) predstavnici Sv. Stolice zadržali su svoja ranija gledišta, zbog čega se stavovi obeju strana, po ovim pitanjima, nisu dovoljno približili ni u beogradskim pregovorima“. ${ }^{12} \mathrm{U}$ pogledu većeg broja ostalih crkveno-političkih pitanja, stanovišta jugoslavenske i vatikanske strane su se u većoj ili manjoj mjeri približila.

Na kraju pregovora jugoslavenska strana je predočila svoje zahtjeve koji su trebali biti predmet završnog akta pregovora. Zahtjevala je da Sv. Stolica iznese svoje stavove vezane za: zabranu zloupotrebe crkve i vjere $\mathrm{u}$ političke svrhe; Ilirski zavod sv. Jeronima; osudu akata terorizma i drugih nasilja protiv SFRJ i preduzimanje mjera protiv svećenika-emigranata koji su učestvovali u njima. Tražila je od Vatikana da onemogući i druge oblike antijugoslavenske djelatnosti svećenika-emigranata, kako bi oni svoju aktivnost ograničavali na crkveno-vjerske poslove. Jugoslavenski pregovarači su zahtjevali da Savezno izvršno vijeće (jugoslavenska vlada) obavezno bude konsultovano prilikom imenovanja jugoslavenskih biskupa.

Vatikanski predstavnici su istakli da u završni dokument treba da uđu slijedeća pitanja: pravo Sv. Stolice da slobodno ostvaruje svoju crkveno-vjersku jurisdikciju nad RKC u Jugoslaviji i pravo biskupa da slobodno opšte sa Sv. Stolicom; da se jugoslavenska vlada obaveže da će obezbjediti potpunu i praktičnu primjenu ustavnih garancija o slobodi savjesti i vjeroispovijesti za sve kategorije građana; da se u školama neće voditi antireligiozna propaganda i da se neće jednostrano sprovoditi odgoj mladih samo na marksističkoj osnovi; pitanje slobode pohađanja vjeronauke; ostvarivanja

12 Isto, Potpredsednik Savezne verske komisije Mato Radulović dostavlja telegram od 4. marta 1965. drugu Dušanu Kvederu, državnom sekretarijatu za inostrane poslove, 5. mart 1965. 
zakonima garantovanih prava slobodnog raspolaganja prostorijama i objektima od strane RKC; sloboda vršenja obreda i podjele sakramenata. Istovremeno su vatikanski predstavnici postavili i pitanje eventualnog unošenja u završni dokument pitanja pristanka roditelja na pohađanje vjeronauka, katoličke štampe, nadzora nad vjerskim školama, praznovanja Božića i drugo.

$\mathrm{Na}$ januarskim pregovorima 1965. godine u Beogradu nije bilo dogovoreno pitanje nivoa odnosa između Vatikana i SFRJ. Odlučeno je da završni dokument ima formu protokola koji bi parafirale obe strane. Kroničar vremena je isticao da je atmosfera u toku pregovora bila korektna jer su pregovori vođeni na miran način, „u duhu razumijevanja za realnost“, bez obzira na suštinske razlike o nekim osnovnim pitanjima. Informacija se dostavljala u povjerljivoj formi, bez davanja izjava i komentara. ${ }^{13}$

Razgovori (pregovori) su ponovo vođeni od 29. maja do 8. juna 1965. u Beogradu. Taj „beogradski nacrt Protokola“ naišao je na teškoće u Vatikanu i pretrpeo izvjesne izmjene usljed pritiska konzervativnih krugova Kurije, dijela rimokatoličkog episkopata Jugoslavije, hrvatske ustaške emigracije, kao i zbog situacije u odnosima sa drugim socijalističkim zemljama, prije svega sa Mađarskom, ČSSR (Čehoslovačkom) i Poljskom. Jugoslavenska strana je zaključila, pošto su vatikanski pregovarači pristali da ponesu u Vatikan nacrt Protokola izrađen u Beogradu juna 1965 (uz izvjesne rezerve), da „to ukazuje da su okviri koji čine formu i sadržinu Protokola tada bili prihvatljivi za Vatikan ili, bolje rečeno, za Državni sekretarijat Vatikana i da su se stvari naknadno pogoršale usljed uticaja napred navedenih faktora". ${ }^{14}$

Uprkos otporu, u Vatikanu je ipak prevladala struja pape Pavla VI i Državnog sekretarijata Vatikana, koja je zastupala liniju sporazuma sa Jugoslavijom. Bili su spremni da žrtvuju izvjesne pretenzije za koje su se intimno nadali da će s protokom vremena biti zadovoljene sa jugoslavenske strane. Za takvu "liniju sporazuma“ sa Jugoslavijom Vatikan je imao više razloga: osnovni je stvaranje stabilnijih uslova za jačanje položaja i aktivnosti RKC u Jugoslaviji. Drugi je ocjena Vatikana da Jugoslavija, po svojoj unutrašnjoj situaciji i tendencijama razvoja, pruža najviše garancija od svih socijalističkih zemalja, ne samo da s njom kao prvom postigne zajednički sporazum (za razliku od onog sa Mađarskom u kome nije bilo zajedničkog teksta) nego da taj sporazum bude i respektovan i da bude i nekakav model za druge socijalističke zemlje.

Zbog svih navedenih razloga, kojima su se pridružili i određeni taktičko-pregovarački motivi, došlo je do otezanja pregovora i njihovog okončanja, odnosno do ponovnog potezanja pitanja garancija o ideološkoj neu-

${ }^{13}$ Isto.

${ }^{14}$ AJ, fond br. 144, f. 101, „Pregovori Jugoslavija - Vatikan u svetlu zadnjih prijedloga vatikanske strane“, 4. mart 1966. 
tralnosti jugoslavenskih škola i „katoličko-doktrinarnoj slobodi“, kao i vatikanske tendencije revizije izvjesnih tačaka nacrta Protokola, naročito vatikanski zahtjev da se tačka o Ilirskom zavodu sv. Jeronima ukloni iz Protokola.

Jugoslavenski pregovarači su zaključili da postoje tri glavna sporna pitanja zbog kojih je Vatikan odugovlačio zaključenje pregovora (ne računajući Koncil): 1) traženje garancija od jugoslavenske Vlade o poštovanju slobode savjesti i vjerskog ubjeđenja rimokatoličkih učenika u rimokatoličkim školama; 2) sloboda doktrinarnog djelovanja RKC; 3) uklanjanje tačke o Zavodu sv. Jeronima iz Protokola.

Vatikan je konačno shvatio da je prvo pitanje, koje je za njega bilo od izuzetnog značaja, još od većeg značaja za Jugoslaviju, pa o njemu nije ni očekivao postizanje sporazuma. Od slične važnosti bilo je i drugo pitanje, ali je ono imalo više praktičan aspekt, kao što je bilo i pitanje „gdje je granica između crkveno-vjerskih i političkih obilježja kod proučavanja katoličke doktrine", zbog kojih je dolazilo ili je moglo doći do praktičnog sukoba između crkve i države. Taj sukob je RKC željela „izbjeći na sebi svojstven način“, to jest dobijanjem koncesije slobodnog doktrinarnog djelovanja. Vezano za Zavod sv. Jeronima, argumenti kojima je Sv. Stolica opravdavala njegovo uklanjanje iz Protokola bili su sporednog značaja. Glavni razlog nalazio se u bojazni jednog dijela jugoslavenskog episkopata „i nekih drugih faktora", od uticaja u Zavodu, zatim u jakoj opoziciji hrvatskih biskupa koji su željeli da zadrže određene privilegije i time spreče „jugoslavenizaciju Zavoda“. Procijenivši da je jugoslavenska strana "jako zainteresovana za Zavod“, Vatikan ga je u nekim trenucima uzimao kao „rezervu kojom uslovljava rješenje drugih pitanja, odnosno eventualno dobijanje novih koncesija i ustupaka“. Odstranjenjem Zavoda iz Protokola želio se izbalansirati ovaj dokument, pogotovo pred očima hrvatskog dijela jugoslavenskog Episkopata. ${ }^{15}$

Za odugovlačenje s pregovorima Vatikan je imao još jedan razlog. Jugoslavenska vlada, kako je procjenjivao, jako je zainteresirana za takav sporazum zbog određenih spoljnopolitičkih motiva, situacije u zemlji, rješenja pitanja vezanih za odnose države i crkve (udruženja rimokatoličkih svećenika, emigracije i drugo). Polazeći od takve procjene, Vatikan se nadao da će jugoslavenska strana popustiti u pitanjima za koje je bio najviše zainteresiran, pa je u tom cilju obnovio neke zahtjeve otežući konačno rješenje.

Jugoslavenska vlada je potom taktički dobro postupila, jer nije pokretala nikakvu inicijativu za sklapanje sporazuma. U javnosti, a i u Vatikanu, jugoslavenska strana je stvorila uvjerenje da je učinila sve da se sporazum potpiše, ali da ne želi sporazum po svaku cijenu preko ucjenjivanja, da je spremna da posao odloži „za bolja vremena“, „kad uslovi budu sazreli“,

\footnotetext{
${ }^{15}$ Isto.
} 
a da je na Vatikanu da pokaže na djelu svoj interes i dobru volju. S druge strane, jugoslavenska strana je isticala kako je pokazala „nekoliko javnih gestova dobre volje" (posmatrači Srpske pravoslavne crkve na Koncilu, prisustvo jugoslavenske delegacije na završnici Koncila itd.), koji su učinili dobar utisak u javnosti. Na taj način Vatikanu je postajalo sve teže objašnjavati zašto oteže pregovore i ustrajava na zahtjevima koji su predstavljali kočnicu za sređivanje odnosa.

Sve navedeno je uticalo na to da je vatikanska procjena situacije postepeno pretrpjela reviziju i približila se zaključku da su interesi obe strane prilično uravnoteženi, te da se od jugoslavenske vlade $u$ tom trenutku ne mogu očekivati novi ustupci. Kazaroli (Cassaroli) i Bonđanino (Bongianino) na kraju su čak izjavili da stagnaciju pregovora smatraju štetnom, da bi „stvari što pre trebalo okončati“ i da nije važno „ko će u tom pravcu prvi pokrenuti inicijativu“. ${ }^{16}$

Razgovori predstavnika Vatikana i ambasade SFRJ u Rimu su ponovo vođeni u Rimu, 4. marta 1966. godine. Predstavnici Sv. Stolice dali su izjave $u$ vezi sa prethodno pomenutim pitanjima. Pri tom je Vatikan nastojao da uvjeri jugoslavenske faktore (kako po formi tako i po sadržini) da je to njihova konačna riječ i da od izraženog minimuma u dokumentu Protokola ne mogu odstupiti.

Jugoslavenska ambasada u Rimu je prije iznošenja svojih ocjena i predloga, 10. marta 1966, željela da iznese svoje mišljenje o sadržini vatikanskih izjava:

„Tačka I verbalne izjave Vatikana konstatuje postignutu saglasnost obeju strana u vezi manjih dopuna teksta Protokola;

Tačka II verbalne izjave Vatikana: Sv. Stolica odstupa od traženja da se $u$ Protokol unesu posebne garancija jugoslovenske vlade ili da jugoslovenska vlada zasebno formuliše garancije u pogledu poštovanja slobode savjesti i verskog ubeđenja katoličkih učenika u školama kao uslov za zaključenje sporazuma. Za uzvrat vatikanska strana je formulisala verbalnu izjavu (nije za objavljivanje), koja rezimira načelne revandikacije RKC. Time je to pitanje formalno likvidirano i ne predstavlja više zapreku za zaključenje sporazuma. Međutim, njihova formulacija izjave o tom pitanju zahteva, po našem mišljenju, i odgovarajuću protiv izjavu iste forme s naše strane (naš predlog izjave dostavljamo u prilogu br. I/2).

Tačka III verbalne izjave Vatikana: Sv. Stolica praktično odustaje od traženja da se u Protokol unese izjava da se „poučavanje katoličke doktrine ne može smatrati aktivnošću političkog karaktera", ali traži kao minimum da se u tekstu Protokola 'verski i crkveni okviri' u kojima mogu da se oba-

\footnotetext{
${ }^{16}$ Isto.
} 
vljaju svećeničke funkcije, determinišu pozivom na kanonsko pravo. Ovo drugo je sa stanovišta praktičnih posledica i u celom kontekstu tačke I glave II Protokola, znatno prihvatljivije od sadržine prve formulacije. Međutim, postavlja se pitanje da li je to prihvatljivo sa formalne strane, zbog toga što se Kanonsko pravo suprotstavlja domaćem zakonodavstvu, jedinom pravnovažećem za građane SFRJ. Ako Vatikan ne odustane ni od ove druge alternative, možda bi se mogao naći kompromis na taj način što bi se rečenici 'u vršenju svojih svećeničkih funkcija' dodale reči '... određenih kanonskim pravom'. Time bi se izbeglo to da se crkveni i verski okviri određuju Kanonskim pravom, dok je za funkcije sveštenika opšte poznato i priznato da ih određuje svaka verska zajednica svojim internim propisima. Ne znamo doduše da li bi Vatikan i ovo prihvatio.

Tačka IV verbalne izjave Vatikana: Izjavom u toj tačci Vatikan praktično definitivno odbija da pitanje Zavoda sv. Jeronima uđe u Protokol. Ostaje verbalna izjava (što odgovara našem minimalnom zahtevu iz Instrukcija Savezne verske komisije, br. 21 od 27. januara 1966), ali uslovljena držanjem jugoslavenskih vlasti, tj. da će se Sv. Stolica držati izjavljenog sve dok naše vlasti ne budu pravile teškoće dolasku svećenika iz određenih pokrajina Jugoslavije u Zavod. Ovo poslednje sa praktičnog stanovišta nema veliki značaj, jer je normalno da se stavovi jedne ili druge strane menjaju prema situaciji koja nastaje unilateralnim aktima jedne od dveju strana. Došli smo do zaključka da Vatikan neće odstupiti od svog sadašnjeg stava i da bi mogli prihvatiti ovu izjavu koja ponavlja tekst iz odgovarajuće tačke Protokola. Ako bismo se zadovoljili datom verbalnom izjavom, onda mislimo da bi bila potrebna naša protuizjava, u smislu predloženom u prilogu br. I/3, koja bi bila u stvari odgovor na uslove iz br. 1 i 3 vatikanske izjave.

Tačka V verbalne izjave Vatikana: Tendencija i smisao predloženog vatikanskog umetka, da apostolski delegat u Beogradu 'ima ujedno i funkcije izaslanika kod Vlade' su jasne i samo potvrđuje da Vatikan želi odnose sa Jugoslavijom na što višem nivou. Vatikansko obrazloženje je sa formalne strane logično, obzirom da u Protokolu stoji da će jugoslovenska vlada imati izaslanika pri Sv. Stolici.

Sv. Stolica je ipak prihvatila jugoslavenske stavove da se u Protokol ne unose vatikanski zahtjevi u pogledu posebnih garancija o poštovanju slobode savjesti i vjerskog ubjeđenja rimokatoličkih učenika u školama i o iznošenju moralnih i dogmatskih „istina“ Rimokatoličke crkve. Ostala je, međutim, pri svom stavu da se iz njene izjave u Protokolu izostavi tačka koja se odnosila na Ilirski zavod sv. Jeronima. U vezi sa oba pitanja Sv. Stolica je dostavila dvije parafirane pismene izjave:

a) „Sveta Stolica je s najvećim žaljenjem saznala da Vlada SFRJ ostaje pri odbijanju da prihvati zahtjev za davanje odgovarajućih garancija 
u pogledu poštovanja slobode savjesti i verskih ubeđenja katoličkih učenika u državnim školama.

Sveta Stolica je smatrala i još uvijek smatra ovaj zahtev osnovnim, jer je državna škola u Jugoslaviji obavezna za sve građane za vreme osmogodišnjeg osnovnog obrazovanja, a ona je i jedina koju mogu da pohađaju oni koji nameravaju nastaviti školovanje (s izuzetkom onih koji se spremaju za sveštenički poziv).

Pitanje je od takvog značaja da je Sveta Stolica sebi morala postaviti pitanje da li je - u nedostatku traženih garantija - uopšte moguće sklopiti predviđene sporazume. Sveta Stolica smatra neophodnim da ostane jasno zapisano da ona ostaje pri svom zahtevu i da se neće moći smatrati zadovoljenom sve dok taj zahtev ne bude prihvaćen, i u meri u kojoj se zahtevu bude izašlo u susret". ${ }^{17}$

Predsjednici savezne i republičkih komisija za vjerska pitanja, uz prisustvo predstavnika Državnog (jugoslavenskog) sekretarijata inostranih poslove, povodom ove izjave Sv. Stolice predložili su da jugoslavenska strana podnese vatikanskoj strani svoju parafiranu izjavu slijedeće sadržine: „Jugoslavenska vlada, ostajući pri izjavi koju je dala u Beogradu 7. juna 1965. o pitanju školske omladine, a u vezi sadržine tačke II napred citirane izjave od strane Sv. Stolice, smatra za potrebno da sa svoje strane izjavi sledeće: Jugoslovenska vlada ponovo izjavljuje da je opštim garancijama navedenim u tački I/1 Protokola zajemčeno svim građanima, bez ikakvih razlika, dosledna primena zakona i drugih propisa kojima se obezbeđuje poštovanje slobode savesti i slobode veroispovedanja vere, koji su zagarantovani Ustavom SFRJ. Jugoslovenska vlada ne može ni jednoj grupi svojih građana dati posebne garancije $u$ tom pogledu“.

U vezi sa Ilirskim zavodom sv. Jeronima, Sv. Stolica je dala slijedeću izjavu: b) „Kao što je u više navrata izjavljeno u toku pregovora, Sv. Stolici nije ni u kom slučaju teško izjaviti da je njena čvrsta namera da se stara da pontifikalni zavod Sv. Jeronima Ilirskog u Rimu uvek i isključivo odgovara ciljevima koji su određeni njegovim statutom. Isto tako, dok bude trajala sadašnja situacija, naime dok jugoslovenska vlada ne bude stvarala teškoće za dolazak dovoljnog broja mladih iz biskupija na teritoriji SFRJ, koje imaju pravo da šalju đake u Zavod, namera je Svete Stolice da u njemu budu primani, kao đaci, samo sveštenici jugoslovenski građani koje šalju biskupi iz Jugoslavije, shodno statutu. Međutim, iz razloga koji su već opširno izloženi, Sv. Stolica ne smatra da može danas uneti takva uveravanja u Protokol. Pitanje će se moći ponovo razmotriti kad bi bile date garancije koje je Sv.

${ }^{17}$ AJ, fond 144, f. 101, Informacija o razgovorima predstavnika Sv. Stolice i Ambasade SFRJ vođenim u Rimu 4. marta 1966. u vezi s pregovorima Jugoslavija - Vatikan, 24. mart 1966. 
Stolica tražila $u$ pogledu poštovanja slobode savesti i verskih ubeđenja katoličkih učenika u državnoj školi“".

Ukoliko bi Sv. Stolica i dalje zahtjevala da se izostavi iz Protokola tačka koja se odnosi na Zavod sv. Jeronima i da umesto toga svoj stav izrazi u izjavi koji je već podnela, predsednici savezne i republičkih komisija za vjerska pitanja jugoslavenskoj vladi bi predložili podnošenje slijedeće parafirane izjave: „Jugoslovenska vlada uzima na znanje izjavu Sv. Stolice da nema nikakvih teškoća da potvrdi da je njena čvrsta namjera da se brine kako bi pontifikalni zavod Sv. Jeronima Ilirskog u Rimu uvek i isključivo služio svrsi kojoj je namenjen na osnovu njegovih statuta. Međutim, iz razloga koje je u više navrata sa svoje strane opširno izložila, jugoslovenska vlada smatra da bi u obostranom interesu bilo korisno kada bi navedena uveravanja Svete Stolice našla svoje mesto u predviđenom Protokolu i sa žaljenjem konstatuje što Sveta Stolica smatra da to ne može učiniti danas. Jugoslovenska vlada takođe smatra da uslovljavanje rešenja pitanja kakvo je traženje Svete Stolice u pogledu katoličkog odgoja školske omladine sa rešenjem pitanja Zavoda Sv. Jeronima Ilirskog u Rimu, ne bi općenito trebalo da bude način rešavanja pojedinih - sadanjih i budućih - otvorenih pitanja iz međusobnih odnosa. Isto tako, u vezi izjave Svete Stolice da sve dok bude trajala postojeća situacija, tj. sve dok Jugoslovenska vlada ne bude postavljala zapreke dolasku dovoljnog broja sveštenika iz biskupija na teritoriji SFRJ (koje imaju pravo da upućuju đake Zavoda), namera je Svete Stolice da u njega budu primani kao pitomci samo sveštenici, jugoslovenski državljani, koje biskupi upućuju iz Jugoslavije u skladu s Pravilima Zavoda. Jugoslovenska vlada izjavljuje da sve dok Zavod bude strogo služio napred navedenoj svrsi, tj. sve dok odgoj pitomaca u Zavodu ne bude vređao postojeće ustavno i društveno-političko uređenje SFRJ i dok se pitomci Zavoda i njihovi biskupi budu pridržavali propisa koji važe za odlazak i boravak građana SFRJ u inostranstvu, sadašnja situacija $u$ tom pogledu se neće menjati“. ${ }^{18}$

S obzirom na ovakav stav Vatikana, jugoslovenska strana je preporučila da se „u izjavi s naše strane“ izostavi tačka kojom se RKC daju određene garancije u pogledu imovinsko-pravnih pitanja. U slučaju da takav stav jugoslovenske strane dovede $u$ pitanje i same pregovore ili ako bi se oni odugovlačili, jugoslovenska delegacija je preporučivala da se iz tadašnje tačke, kojom se „s naše strane daju određene garancije u pogledu imovinskopravnih pitanja“, ostavi samo konstatacija da prema važećim propisima RKC može imati i ubuduće pravo svojine na nepokretnostima i da može vršiti popravke postojećih i kupovinu ili izgradnju novih objekata za svoje potrebe. Zalagali su se da se povuče drugi stav ove tačke prema kojem se

\footnotetext{
${ }^{18}$ Isto.
} 
vlada SFRJ obavezivala da će se založiti da se crkvi vrate objekti koji su u njenom vlasništvu. ${ }^{19}$

Prilikom razgovora predstavnika Sv. Stolice i Ambasade SFRJ u Ri$\mathrm{mu}, 4$. marta 1966, vatikanski predstavnici su predlagali da se u nacrt Protokola unesu slijedeće dopune: a) da se u tekstu riječ „pregovori“ zamjeni riječu „razgovori“, budući da termin pregovori ne odgovara ograničenoj formi i sadržini dokumenta. Jugoslavenska strana je insistirala da u Protokolu ostane formulacija da su Jugoslavija i Sveta Stolica vodili „pregovore“. Preporučeno je da se prihvati vatikanski predlog samo ako „naš stav budu uslovljavali odugovlačenjem“; b) da se u izjavi Svete Stolice, „u kojoj se potvrđuje principijelan stav da delatnost katoličkih sveštenika u vršenju njihovih svešteničkih dužnosti treba da se odvija u verskim i crkvenim okvirima.., nadodaju na reči 'određenim kanonskim pravom', tako da ovaj stav u celini glasi: '1. Sveta Stolica potvrđuje principijelan stav da delatnost katoličkih sveštenika, $u$ vršenju njihovih svešteničkih dužnosti, treba da se odvija $u$ verskim i crkvenim okvirima određenim kanonskim pravom i da shodno tome ni jedan od njih ne može da zloupotrebi svoje verske i crkvene funkcije u svrhe koje bi stvarno imale politički karakter. Sveta Stolica je spremna da uzme u razmatranje slučajeve na koje bi vlada SFRJ smatrala za potrebno da joj ukaže u tom pogledu; c) da se u glavi IV Protokola apostolskom delegatu prizna od strane Jugoslovenske vlade da ima ujedno i funkciju izaslanika kod Vlade, čime bi bio u istom položaju kao i izaslanik Vlade SFRJ pred Svetom Stolicom, pa ova glava u celini glasi: „U pogledu načina olakšavanja daljih kontakata između Vlade SFRJ i Svete Stolice, Vlada SFRJ je spremna da omogući boravak Apostolskom delegatu u Beogradu koji će imati ujedno i funkciju izaslanika pri istoj Vladi, s tim da ona sa svoje strane zadržava pravo da odredi svog izaslanika pri Svetoj Stolici. Sveta Stolica je spremna da primi izaslanika Vlade SFRJ i koristiće se mogućnošću za upućivanje Apostolskog delegata u Beograd“.

Jugoslavenska strana je dala saglasnost da se predlog može prihvatiti, jer je za apostolskog delegata tražen jednak tretman koji ima i predstavnik SIV-a pri Svetoj Stolici. U slučaju da vatikanska strana ne prihvati jugoslavenski stav i da se ne unesu predložene dopune, zaključeno je: „S naše strane bi trebalo predložiti da se u prvom stavu brišu reči 'verskim i crkvenim' i ujedno dati parafiranu pismenu izjavu koja glasi: 'U vezi izjave Svete Stolice pod II/1 Protokola prema kojoj Sveta Stolice potvrđuje principijelan stav da delatnost katoličkih sveštenika, u vršenju njihovih svešteničkih dužnosti, treba da se odvija u (verskim i crkvenim) okvirima određenim kanonskim pravom, Jugoslovenska vlada želi naglasiti da se po sebi razume da

\footnotetext{
${ }^{19}$ Isto.
} 
saglasnost postupaka katoličkih sveštenika sa kanonskim pravom ni u kom slučaju ne može uticati na primenu jugoslovenskih propisa".

Italijanski predstavnik je objasnio da u praksi nije predviđeno da Sveta Stolica daje zajedničke izjave po završetku pregovora, već da svaka strana daje zasebne izjave koje se prethodno zajednički usaglašavaju. Jugoslavenski pregovarači su prihvatili taj predlog. Predstavnik Svete Stolice je postavio pitanje da li će se Protokol objaviti u Službenom listu SFRJ i stavio do znanja da Sveta Stolica ne praktikuje objavljivanje u svom službenom listu već u Osservatore romano. Protokol je trebalo da se potpiše pošto ga prihvati Savezno izvršno veće, što je značilo da ga je vlada trebala ratifikovati. Pored toga jugoslavenski potpisnik dobijao je akreditiv za potpisivanje od državnog sekretara za inostrane poslove. Jugoslavenska strana je, iz tih razloga, smatrala da Protokol treba objaviti u Službenom listu SFRJ. Protokol, kako je predviđeno, biće istovremeno objavljen u odgovarajućoj formi u dnevnoj štampi. Potvrđena je ranija saglasnost da će se Protokol potpisati u Beogradu. S vatikanske strane trebalo je da potpisnik bude Kazaroli, koji je imao akreditiv državnog sekretara Vatikana. Zato su vatikanski pregovarači željeli da imaju državnog sekretara za inostrane poslove. ${ }^{20}$

Ambasador u Rimu Ivo Vejvoda, u prepisci sa Državnim sekretarijatom za inostrane poslove i Saveznom vjerskom komisijom, od 23. marta 1966, iznio je svoje ocjene i nedoumice povodom pregovora Jugoslavije i Vatikana:

„1. Mislimo da postoji nesporazum između naših predloga za okončanje pregovora Jugoslavija - Vatikan (vašeg br. 49724) u pogledu procedure i metoda za rešenje preostalih otvorenih pitanja.

2. Nije problem utvrđivanja teksta Protokola jer je to praktično već obavljeno. Suština stvari je u tome što Vatikan čeka odgovor jugoslavenske vlade na svoje zadnje predloge, pre nego što Casaroli ide u Beograd na završetak pregovora, odnosno potpisivanje dokumenta. Ako vatikanskoj strani saopštimo da delegacija dođe u Beograd predloženog datuma, smatraće da (su) njeni zadnji predlozi usvojeni. Ako pak kažemo da će se o njima raspravljati tek u Beogradu, onda ako i pristanu može se desiti da se ponovo vrate u Rim radi konsultovanja, što bi značilo ne samo ponovno odlaganje potpisivanja već da smatramo da i politički ne bi bilo poželjno. Takvom procedurom ne bi se skratio tok pregovora već produžio i komplicirao.

3. Mi smo u zadnjim predlozima Vatikana poslali opširnu informaciju sa ocenama i konkretnim predlozima za okončanje pregovora. Predlažemo da se u Beogradu na osnovu poslatog materijala zauzmu odgovarajući stavovi, koje bismo mi kao odgovor saopštili vatikanskoj strani. Time bi se raščistila preostala pitanja i izvršile sve potrebne pripreme, tako da bi vati-

${ }^{20}$ Isto. 
kanski pregovarači ovde na licu mesta mogli dobiti definitivnu saglasnost nadležnih i potom otići u Beograd sa ovlašćenjem za potpisivanje dokumenta.

4. Ako usvojite predloženu proceduru, koju smatramo korisnom i celishodnom, molimo da nam dostavite definitivan odgovor u vezi pitanja na koje se odnose predlozi u našoj informaciji pov. br. 126/66 pod tačkom 8 do 12 i od 14 do 18, kao i u vezi dostavljenog priloga I u celini, koji sadrži naš predlog verbalnih izjava jugoslovenske Vlade. Uzgred, te izjave ne možemo usaglašavati sa vatikanskom stranom, jer su strogo unilateralne, kao što ni oni nisu učinili sa nama u formulisanju svojih izjava.

5. Ukoliko i posle ovog našeg objašnjenja ostanu i dalje neke nejasnoće predlažemo da Mandić dođe u Beograd avionom 25. marta. Molimo hitno odgovorite - Vejvoda“. ${ }^{21}$

Glavni pravni savjetnik DSIP-a, prof. Bor. T. Blagojević, dao je 29. marta 1966. slijedeće mišljenje o razgovorima predstavnika Sv. Stolice i Ambasade SFRJ (vezano za Protokol), vođenim u Rimu 4. marta 1966:

„1. U pogledu podnete parafirane izjave Svete Stolice (priložena Informacija ad I/a) o garancijama u pogledu poštovanja slobode savesti i verskih ubeđenja katoličkih učenika u državnim školama, saglasni smo da se s naše strane podnese parafirana pismena izjava kao na strani 2 priložene informacije;

2. Po pitanju parafirane izjave Svete Stolice o Zavodu sv. Jeronima (priložena Informacija ad I/b), sa taktičkog stanovišta vođenja pregovora, potrebno je insistirati da ostane u Protokolu o pregovorima II/2 tačka o Zavodu Sv. Jeronima. Ukoliko Sveta Stolica ostane i dalje pri svom stavu da se izostavi iz Protokola tačka koja se odnosi na Zavod sv. Jeronima, onda treba jugoslovenska strana da podnese pismenu parafiranu izjavu, kao na strani 4 priložene informacije sa sledećim izmenama:

Stavovi 1 i 2 Izjave ostaju kao u priloženoj Informaciji Savezne komisije za verska pitanja. Stav 3 Izjave postaje našim predlogom stav 4 (sa izmenom o kojoj je dalje reč), a stav 3 da glasi: 'U vezi s tim sve dok Zavod bude strogo služio svojoj svrsi, tj. sve dok odgoj pitomaca u Zavodu ne bude vređao postojeće ustavno i društveno-političko uređenje SFRJ i dok se pitomci Zavoda i njihovi biskupi budu pridržavali propisa koji važe za odlazak i boravak građana SFRJ u inostranstvu, sadašnja situacija neće imati potrebe da se menja'.

Iza ovoga bi došao stav 4 (sadašnji stav 3), koji bi glasio kao u predlogu Verske komisije, s tim da se mesto reči „ne bi općenito trebalo da bude, stavi 'ne može da bude', ili možda čak i 'nedopušteno je', pošto treba

\footnotetext{
${ }^{21}$ AJ, fond 144, f. 101.
} 
svako ovakvo povezivanje sadržine našeg pravnog poretka odbiti izrično i odlučno.

S obzirom na ovakav stav Sv. Stolice treba iz taktičkih razloga po pitanju tačke Protokola o Zavodu sv. Jeronima postupiti kako sledi:

a) najpre insistirati da se uopšte izostavi tačka I/3 Protokola o pregovorima kojom se Katoličkoj crkvi daju određene garancije u pogledu imovinsko-pravnih pitanja; b) ukoliko ne pristanu da se uopšte izostavi pitanje o imovinsko-pravnim pitanjima iz protokola, onda je dati slično sadašnjoj formulaciji u Protokolu o pregovorima (tačka I/3) samo kao parafiranu pismenu izjavu; c) ukoliko Sv. Stolica bude insistirala da ipak nešto uđe u Protokol o imovinsko-pravnim pitanjima, onda bi eventualno u tačku I/1 Protokola mogla biti uneta samo sadržina prvog stava sadašnje tačke $\mathrm{I} / 3$, tj. da po našim važećim propisima Katolička crkve može imati pravo svojine na nepokretnostima za svoje potrebe; d) kao četvrta alternativa koja bi predstavljala najdalji ustupak Sv. Stolici, bilo bi ono što je rečeno pod c), s tim da se uz takvu dopunu tačke I/1 Protokola da i pismena parafirana izjava koja bi glasila: 'Vlada SFRJ preporučiće nadležnim društveno-političkim zajednicama da založe svoj uticaj u cilju stavljanja na upotrebu i korišćenje verskim zajednicama objekata koji su njihovo vlasništvo, a sada su u upotrebi drugih korisnika'.

3) Po pitanju predloga Svete Stolice (II/a priložene informacije) da se u tekstu naslova Protokola umesto reči 'pregovori' unese reč razgovori', ako Sveta Stolica bude insistirala na svom predlogu, isti se može prihvatiti.

4. U pogledu predloga Svete Stolice (II/b priložene informacije) u kojoj se potvrđuje principijelan stav da delatnost katoličkih sveštenika $u$ vršenju njihovih svešteničkih dužnosti treba da se odvija u verskim i crkvenim okvirima.., nadodaju na kraju reči 'određenim kanonskim pravom', zauzeti postupno stavove kako sledi: a) zahtevati da se iz određene tačke Protokola brišu reči 'određenim kanonskim pravom', sa sledećim obrazloženjem: unošenjem ovih reči Sveta Stolica želi da odredi kriterije za pravnu kvalifikaciju delatnosti katoličkog sveštenika U vršenju njihovih svešteničkih dužnosti, za koje mi ne možemo pristati da se prejudiciraju kanonskim pravom, pošto mi imamo naše zakone. Naša strana određuje osnov po kome se vrši primena prava u našoj zemlji; b) ukoliko vatikanska strana ne prihvati napred navedeni naš stav da se iz teksta izbace pomenute reči, onda dati parafiranu pismenu izjavu koja bi glasila: 'U vezi s izjavom Sv. Stolice pod II/1 Protokola prema kojoj Sv. Stolica potvrđuje principijelan stav da delatnost katoličkih sveštenika, u vršenju njihovih svešteničkih dužnosti, treba da se odvijaju u (verskim i crkvenim) okvirima određenim kanonskim pravom, jugoslovenska vlada želi naglasiti da se po sebi razume da saglasnost postupaka katoličkih sveštenika sa kanonskim pravom ni u kom slu- 
čaju ne može uticati na njihove obaveze poštovanja i pridržavanja jugoslovenskih propisa'.

U ovom slučaju je nužno svakako sadašnji stav 1 razdvojiti na dva stava (kao što je to i bio slučaj u ranijim nacrtima Protokola) tako da bi stav 2 predstavljao čist Kanzelparagraf, koji, bar formalno, ne bi bio vezan za stav 1. No to sve samo ako bi pregovori zbog ovoga bili odloženi, tako da bi prethodno trebalo vršiti pritisak da se izostave reči 'određenim kanonskim pravom', pa čak možda opet odložiti za izvesno vreme pregovore, kako bi Sveta Stolica videla jasno da nama nije po svaku cenu stalo da se Protokol što pre potpiše, ili uopšte potpiše.

5. Može se prihvatiti da se Apostolskom delegatu prizna od strane jugoslovenske vlade i funkcija izaslanika pri istoj. Glava IV Protokola bi glasila: 'U pogledu načina olakšavanja daljih kontakata između Vlade SFRJ i Svete Stolice, Vlada SFRJ je spremna da omogući boravak Apostolskom delegatu u Beogradu, koji će imati ujedno i funkciju izaslanika pri istoj Vladi, s tim da ona sa svoje strane zadržava pravo da odredi svog izaslanika pri Svetoj Stolici'.

6. Po pitanju načina objavljivanja Protokola o pregovorima, naš je stav da treba Protokol objaviti u Službenom listu SFRJ, pa u tom smislu treba i odgovoriti Svetoj Stolici. Beograd, 29. marta 1966."

Obe pregovaračke strane prišle su pregovorima sa ciljem sređivanja međusobnih odnosa, ali bez iluzija da će moći riješiti sva sporna pitanja. Imale su u vidu da će se neka od njih moći rješavati tek kada za njih sazru uslovi. U pregovorima se išlo za tim da se nađu zajednička rješenja za pitanja o kojima je bilo moguće postići sporazum. Jugoslavenska strana je polazila od činjenice da je sređivanje odnosa sa Rimokatoličkom crkvom moguće samo na bazi Ustava i drugih zakona SFRJ i na način kako su oni regulisani sa drugim vjerskim zajednicama. U tom duhu postavljala je konkretne zahtjeve i davala odgovore na pitanja predstavnika Svete Stolice.

S druge strane, predstavnici Svete Stolice su izjavili da neće činiti nepremostive teškoće uslijed toga što je položaj Rimokatoličke crkve u SFRJ regulisan na bazi Ustava i zakona zemlje, kao i da odvojenost crkve od države ne mora biti razlog loših odnosa, ako iz takvog stanja ne rezultira neprijateljski stav države prema crkvi i religiji. Svoja mišljenja, kako su isticali, zasnivali su na informacijama jugoslavenskih biskupa i predstavkama koje su biskupi upućivali Vladi i drugim državnim organima, što se negativno ispoljavalo u toku pregovora. Sveta Stolica je realnije ocjenjivala stvaran

${ }^{22}$ AJ, fond 144, f. 101, Državni sekretarijat za inostrane poslove, Služba za pravne poslove - Saveznoj komisiji za verska pitanja, pov. br. 47547, 29. mart 1966. 
položaj i mogućnosti djelovanja RKC u Jugoslaviji od jugoslavenskog (naročito hrvatskog) episkopata. Ipak, u nizu značajnih pitanja koja su bila predmet pregovora (sveštenička emigracija, imenovanje biskupa, sveštenička udruženja, odgoj omladine i drugo) nije postignut sporazum zbog suprotnih gledišta Sv. Stolice. Na ovakav stav Sv. Stolice uticao je i jugoslavenski episkopat, koji je Vatikanu upućivao pismene primjedbe na nacrt Protokola i na sam sadržaj pregovora. Vlada Jugoslavije je zbog ponašanja jugoslavenskog rimokatoličkog episkopata očekivala da će pojedini hrvatski biskupi i poslije potpisivanja Protokola opstruirati afirmaciju sporazuma i boljih odnosa između jugoslavenske države i Rimske crkve. ${ }^{23}$

Pregovori su konačno završeni u aprilu 1966, utvrđivanjem Protokola o pitanjima za koje je postignuta saglasnost. Postoje izjave o izvjesnim konkretnim pitanjima o kojima nije postignut sporazum, ali one nisu ušle $\mathrm{u}$ Protokol. Istoričarka iz Zagreba dr Katarina Spehnjak je dala koncizan pregled završnih pregovora i potpisivanja Protokola između Vatikana i Jugoslavije: „Pregovori su vođeni u nekoliko navrata - u lipnju 1964. u Rimu, dvaput u Beogradu 1965. i u proljeće 1966. ponovno u Rimu. Sporazum o tome potpisali su 25. lipnja 1966. u Beogradu Agostin Cassaroli, predstavnik Vatikana, i Milutin Morača, predstavnik jugoslavenske vlade, i to u obliku Protokola, kako se formalno naziva zapisnik pregovora, koji je imao učinak sporazuma među državama. Dokument u četiri članka utvrđuje pitanja o kojima je postignuto slaganje: jugoslavenske vlasti, u skladu s ustavnim odredbama, potvrđuju slobodu vjeroispovijesti, odvojenost crkve i države te jednakopravnost svih vjerskih zajednica i jamče Katoličkoj crkvi (KC) slobodno obavljanje vjerskih poslova, uvažavajući nadležnost Svete (Sv.) Stolice nad KC-om u Jugoslaviji u duhovnim stvarima. Sv. Stolica, pak, istodobno izjavljuje da svećenici ne mogu svoje crkvene i vjerske funkcije zloupotrebljavati u političke svrhe te osuđuje političko nasilje i politički terorizam. Dijelom Protokola smatrane su, nadalje, i verbalne izjave jedne i druge strane, dane odvojeno, o pitanjima o kojima nije postignuta suglasnost, a čiji je broj bio veći od onoga o kojima je suglasnost postignuta: s jugoslavenske strane inzistiralo se, na primjer (npr.), na utjecaju pri izboru biskupa KC-a, radu Zavoda sv. Jeronima u Rimu i slično, a s vatikanske strane na utjecaju u odgojno-obrazovnome sustavu, povratu oduzete imovine nakon rata i slično. Svi su ti zahtjevi u obliku izjava, a na traženje obje strane, postali sastavnim dijelom Protokola....". ${ }^{24}$

${ }^{23}$ Isto, Informacija Savezne komisije za verska pitanja o odnosima između SFRJ i Svete Stolice, 26. maj 1966.

${ }^{24}$ K. Spehnjak, Tumačenje Protokola o odnosima Jugoslavije i Vatikana iz 1966. u političkoj javnosti Hrvatske, u: Dijalog povjesničara - istoričara, 3, Zagreb 2001, 473. 
Poslije potpisivanja Protokola, 25. juna 1966, jugoslavensko-vatikanski odnosi su išli uzlaznom linijom, što će kulminirati 1971. posjetom Josipa Broza Tita papi Pavlu VI. Nakon Brozove posjete Vatikanu u Jugoslaviji će se ubrzati procesi dezintegracije zemlje i naročito jačanje nezavisnosti, odnosno konfederativnog položaja Socijalističke Republike Hrvatske. U prilog širenja hrvatstva i hrvatske nacionalne ideje, nekadašnji ilirski (srpski, pa jugoslavenski) Zavod sv. Jeronima Vatikan će 1971. preimenovati u Hrvatski papinski zavod sv. Jeronima. Američki predsjednik Ronald Regan će uspostaviti neposrednu kontrolu nad Vatikanom preko pape Jovana Pavla II, koji će postati produžena poluga američkog pritiska na SSSR i zemlje Varšavskog pakta.

Nikola Žutić

THE YUGOSLAV - HOLY SEE PROTOCOL IN 1966.

\section{Summary}

This article analyses the process of the normalisation of the relations between the Socialist Yugoslavia and Holy See, between the 1945 and 1966, when the Procotol betwen the two states was signed. Beginning of this period was marked with the difficulites in the relations, mostly rooted in the firm athestic ideological standpoints that Yugoslav Communist regime showed toward the the Vatican. Later this firm standpoint was changed with the wider opening of the Tito's Yugoslavia towards West. The author stress that the Protocol was signed in period when in Yugoslavian political circles a certian anti-Serbian stream started to rise. After the signing of the Protocol mutual relations improved, leading to the Tito's visit o the Pope Paul VI. This article is based on the author's research in Archiv of Yugoslavia. 